\title{
Review
}

\section{Bromelain as a Treatment for Osteoarthritis: a Review of Clinical Studies}

\author{
Sarah Brien ${ }^{1}$, George Lewith ${ }^{1}$, Ann Walker², Stephen M. Hicks² and Dick Middleton ${ }^{3}$ \\ ${ }^{1}$ University of Southampton, Southampton, ${ }^{2}$ University of Reading, Reading and ${ }^{3}$ Medic Herb UK Ltd, UK
}

\begin{abstract}
Bromelain, an extract from the pineapple plant, has been demonstrated to show anti-inflammatory and analgesic properties and may provide a safer alternative or adjunctive treatment for osteoarthritis. All previous trials, which have been uncontrolled or comparative studies, indicate its potential use for the treatment of osteoarthritis. This paper reviews the mechanism of its putative therapeutic actions, those clinical trials that have assessed its use in osteoarthritis to date, as well as considering the safety implications of this supplement for osteoarthritis and reviewing the evidence to date regarding the dosage for treating this condition. The data available at present indicate the need for trials to establish the efficacy and optimum dosage for bromelain and the need for adequate prospective adverse event monitoring in such chronic conditions as osteoarthritis.
\end{abstract}

Keywords: bromelain - herbal - osteoarthritis - proteolytic enzymes - review

\section{Introduction}

In recent years, a number of clinical studies have appeared to substantiate one of the traditional therapeutic uses of extracts of bromelain, namely, in the treatment of inflammatory disorders of the musculoskeletal system. This paper sets out to review the clinical evidence for the use of bromelain in osteoarthritis.

Osteoarthritis is the most common form of arthritis in Western countries; in the USA prevalence of osteoarthritis ranges from $3.2 \%$ to $33 \%$ dependent on the joint (1). Its prevalence increases with age, and sex differences are evident (2). It can also create substantial disability (2). The risk of disability attributable to knee osteoarthritis alone is greater than any other medical disorder in the elderly (3), apart from cardiac diseases. Risk factors associated with both the development (e.g. heredity, age, female sex, obesity, trauma) and progression of the disease [e.g. obesity, low bone density, non steroidal anti-inflammatory drug (NSAID) use] have been identified (4); obesity is considered a major risk factor for both the development and progression of osteoarthritis $(5,6)$. As allopathic medicine is unable to halt this progression

For reprints and all correspondence: Dr Sarah Brien, Complementary Medicine Research, Primary Medical Care, Aldermoor Health Centre, Aldermoor Close, Southampton, Hampshire, S016 5ST. Tel. +44 2380

241068; Fax: +44 23808070 1125; E-mail: sbb@ soton.ac.uk conventional medical treatment is aimed at decreasing pain and improving function by the use of NSAIDs, other analgesics, steroidal joint injections and, as a last resort, joint replacement. Because the high incidence of adverse events, especially gastrointestinal, associated with both non-selective and COX-2selective NSAID use is high (7-9), effective but safer alternative treatments would be of benefit to osteoarthritis sufferers.

\section{Bromelain}

Bromelain is a food supplement that may provide an alternative treatment to NSAIDs for patients with osteoarthritis. Bromelain is a crude, aqueous extract obtained from both the stem and fruit of the pineapple plant, which contains a number of proteolytic enzymes $(10,11)$ and has shown potentially beneficial effects due to its anti-inflammatory and analgesic properties. Currently, bromelain is used for acute inflammation and sports injuries. It is not a licensed medical product and is freely available to the general public in health food stores and pharmacies in the USA and Europe.

\section{Mechanism of Action}

The mechanisms of action have been reviewed (10-12). Bromelain has been shown to have a number of beneficial

The online version of this article has been published under an open access model. Users are entitled to use, reproduce, disseminate, or display the open access version of this article provided that: the original authorship is properly and fully attributed; the Journal and Oxford University Press are attributed as the original place of publication with the correct citation details given; if an article is subsequently reproduced or disseminated not in its entirety but only in part or as a derivative work this must be clearly indicated. 
properties including anti-inflammatory and analgesic actions in addition to its anti-oedematous, antithrombotic and fibrinolytic effects (11). Experimental evidence suggests that bromelain's action as an anti-inflammatory is mediated via the following factors: (i) by increasing serum fibrinolytic activity (13), reducing plasma fibrinogen levels (14) and decreasing bradykinin levels (which results in reduced vascular permeability) and hence reducing oedema and pain (15); (ii) by mediating prostaglandin levels (by decreasing levels of $\mathrm{PGE}_{2}$ and thromboxane $\mathrm{A}_{2}$ ); and (iii) through modulation of certain immune cell surface adhesion molecules (16-20), which play a role in the pathogenesis of arthritis (21). However, many of these studies are of poor quality and further data is needed to clarify definitive mechanisms of its action.

Data have also indicated that bromelain has analgesic properties, for example in inflammatory pain in humans (22), human urogenital inflammation (23), and in various animal inflammatory models $(13,23)$. Its analgesic properties are thought to be a result of its direct influence on pain mediators such as bradykinin (15), as well as its indirect effects through its anti-inflammatory actions (e.g. reduction in oedema, debris and immune complexes), which reduce pain.

\section{Clinical Studies}

Bromelain was first reported to be of value as an analgesic/ anti-inflammatory for use in both rheumatoid arthritis and osteoarthritic patients in 1964 (24). Clinical trials have assessed the effectiveness of bromelain most frequently using preparations containing differing complexes of proteolytic enzymes and differing concentrations of bromelain. Three complexes have been used: (i) Phlogenzyme ${ }^{\mathrm{TM}}$ (PHL), which contains the proteolytic enzymes bromelain $(90 \mathrm{mg} / \mathrm{tab}$ ), trypsin and rutin; (ii) Wobenzyme ${ }^{\mathrm{TM}}$ (WOB) which contains bromelain (45 $\mathrm{mg} / \mathrm{tab}$ ), papain, trypsin, chymotrypsin, pancreatin, lipase and amylase; and (iii) Wobenzym $\mathrm{N}^{\mathrm{TM}}$ (WOB-N) which contains bromelain (45 mg/tab), trypsin, papain, chymotrypsin, pancreatin and rutin. Bromelain has been assessed in the treatment of osteoarthritis of two joints, i.e. the knee (24-30) and the shoulder (as assessed under the global term periarthritis humeroscapularis) $(31,32)$. Tables 1 and 2 summarise those studies that have investigated the effect of bromelain in knee and shoulder osteoarthritis, respectively.

The majority of studies assessing bromelain for osteoarthritis have been either open studies $(24,30)$ or equivalence studies designed to assess comparative effectiveness and safety against standard NSAIDs treatment (25-29, Klein, 1994, unpublished data.). A number of these studies are unpublished [as reviewed by Leipner et al. (25)], including two placebo controlled studies designed to assess the efficacy of bromelain in knee osteoarthritis. The following sections will review the studies that have been carried out to date. Direct comparison between these trials is difficult as different dosages or preparations of bromelain have been administered. The majority of the studies have methodological issues that make it difficult to draw definite conclusions.

\section{Bromelain for Knee Osteoarthritis}

Ten studies have been identified that have assessed bromelain in osteoarthritis of the knee (Table 1). The earliest reported studies investigating bromelain were a series of case reports on 28 patients, with moderate or severe rheumatoid or osteoarthritis, described by Cohen and Goldman (24). The studies reported indicated that the use of bromelain, at varying doses (these doses were relatively low as compared to subsequent studies) and differing duration, had positive clinical effects in 18 patients (as measured by assessment of reduction in soft tissue swelling, pain and/or joint stiffness) and no adverse events associated with the medication were reported in any of these case reports. This data therefore provided a plausible basis for the further assessment of bromelain in musculoskeletal disorders.

Four unpublished studies: two placebo-controlled, randomised trials and two controlled and randomised studies were reported in the review by Leipner et al. (25). These studies were designed to assess the comparative effectiveness of bromelain with a standard treatment, the NSAID diclofenac (DF). No significant improvement in outcome was observed in either of the two placebo-controlled trials but both are of poor methodological quality. The outcome measure for one of the unpublished trials may have been inappropriate and both studies may have been inadequately powered (sample size in both studies was $n=60$ ). In addition, in common with the majority of studies assessing bromelain for this indication, the treatment period was short (3 weeks duration) as compared to normal herbal practice where this preparation may be prescribed for 2-3 months in the first instance. Definitive conclusions cannot therefore be drawn from these two efficacy studies. However the safety and tolerability in both these studies appeared adequate as only minor (mainly gastrointestinal) adverse events were reported and dropout rates were low (5\% in both studies). Klein and Kullich's (27) double blind, randomised, controlled trial of 73 patients with osteoarthritis of the knee compared a commercial proteolytic enzyme preparation (Phlogenzym $\left.{ }^{\circledR}\right)$ containing bromelain (among other proteolytic enzymes) with a dose of DF (100-150 mg/day) (24). They report an equivalent reduction in pain indices of $80 \%$ for the two treatments during 3 weeks of therapy and 4 weeks of follow-up with few adverse reactions to either treatment. The two unpublished comparative trials identified that treatment with bromelain $(540 \mathrm{mg} /$ day as part of the complexes PHL or WOB) reduced osteoarthritis symptoms and that the reduction was comparable to standard treatment. However, again the treatment period in both these studies was short and it is not possible to identify if the study was adequately powered as no sample size calculations are available. Tolerability was good with both PHL and WOB; however, a high rate of adverse drug reactions (none serious) was reported in the WOB study, with a rate of reporting of 50\% of subjects in the WOB and the DF treatment groups. These unpublished reports therefore show equivocal evidence in support of bromelain in osteoarthritis, but highlight the potential safety issue. 
Table 1. Summary of studies assessing the effectiveness of bromelain as a treatment for osteoarthritis of the knee

\begin{tabular}{|c|c|c|c|c|c|c|c|c|c|}
\hline Authors & Study design & $n^{+}$ & Dosage & Condition & $\begin{array}{l}\text { Treatment } \\
\text { period }\end{array}$ & Follow up & Adverse events & Primary outcome & Conclusion \\
\hline $\begin{array}{l}\text { Cohen \& } \\
\text { Goldman (24) }\end{array}$ & $\begin{array}{l}\text { Uncontrolled } \\
\text { series of case } \\
\text { reports }\end{array}$ & 29 & $\begin{array}{l}60-160 \mathrm{mg} / \mathrm{day} \\
\text { bromelain }\end{array}$ & $\begin{array}{l}\text { Moderate to } \\
\text { severe arthritis } \\
\text { (25 RA; 2 OA; } \\
10 \text { A and RA; } \\
\text { and } 1 \text { gout) }\end{array}$ & $\begin{array}{l}3 \text { weeks to } \\
13 \text { months }\end{array}$ & $\begin{array}{l}\text { When soft } \\
\text { tissue } \\
\text { swelling }\end{array}$ & None reported & $\begin{array}{l}\text { Soft tissue } \\
\text { swelling and pain }\end{array}$ & $\begin{array}{l}\text { Reduction in soft } \\
\text { tissue swelling } \\
\text { in } 72.4 \%\end{array}$ \\
\hline \multirow{4}{*}{$\begin{array}{l}\text { Leipner } \text { et al. }(25) \text {. } \\
\text { Series of unpublished } \\
\text { studies in OA involving } \\
\text { Phlogenzym } \\
\text { Wobenzym }^{\mathrm{TM}} \text { (WHL), } \\
\text { Wobenzym } \mathrm{N}^{\mathrm{TM}} \text { (WOB-N). } \\
\text { Studies investigating OA } \\
\text { of knee are reported }\end{array}$} & $\begin{array}{l}\text { (i) placebo } \\
\text { controlled DB } \\
\text { RCT }\end{array}$ & $\begin{array}{l}\text { (ii) } 60 \\
\text { (ref. 31) }\end{array}$ & $\begin{array}{l}\text { PHL } 3 \times 2 \text { tabs/ } \\
\text { day }(540 \mathrm{mg} / \\
\text { day bromelain) } \\
\text { versus placebo }\end{array}$ & $\begin{array}{l}\text { Arthrosis of } \\
\text { the knee } \\
(57 \%) \text { or } \\
\text { hip (43\%) }\end{array}$ & 3 weeks & NK & $\begin{array}{l}\text { No SAE reported. } \\
\text { Two ADR reported } \\
\text { in PHL group }\end{array}$ & $\begin{array}{l}\text { Sum score of various } \\
\text { pain (active, pressure, } \\
\text { rest, night) and } \\
\text { dysfunction (four } \\
\text { point category scale) } \\
\text { measures }\end{array}$ & $\begin{array}{l}\text { Similar reduction in } \\
\text { primary outcome for } \\
\text { both groups. NS group } \\
\text { differences. Drop } \\
\text { out } n=(1 \text { PHL })\end{array}$ \\
\hline & $\begin{array}{l}\text { (ii) placebo } \\
\text { controlled } \\
\text { DB RCT }\end{array}$ & $\begin{array}{l}\text { (ii) } 60 \\
\text { (ref 32) }\end{array}$ & $\begin{array}{l}\text { PHL } 3 \times 2 \\
\text { tabs/day } \\
(540 \mathrm{mg} / \mathrm{day} \\
\text { bromelain }) \\
\text { versus placebo }\end{array}$ & $\begin{array}{l}\text { OA of the } \\
\text { knee joint }\end{array}$ & 3 weeks & NK & $\begin{array}{l}\text { No SAE reported. } \\
\text { Two ADR reported } \\
\text { in PHL group }\end{array}$ & Lequesne index & $\begin{array}{l}\text { Reduction in primary } \\
\text { outcome for both groups; } \\
\text { NS group differences. } \\
\text { Drop out } n=3 \text { (1 PHL) }\end{array}$ \\
\hline & $\begin{array}{l}\text { (iii) Comparative } \\
\text { DB, RCT }\end{array}$ & $\begin{array}{l}\text { (ii) } 60 \\
\text { (ref 38) }\end{array}$ & $\begin{array}{l}\text { PHL } 3 \times 2 \\
\text { tabs/day }(540 \\
\text { mg/day } \\
\text { bromelain }) \\
\text { versus DF } \\
(100-150 \mathrm{mg} / \text { day })\end{array}$ & $\begin{array}{l}\text { OA of the } \\
\text { knee joint }\end{array}$ & 3 weeks & NK & $\begin{array}{l}\text { No SAE reported. } \\
\text { One ADR } \\
\text { (0 PHL; } 1 \text { DF) }\end{array}$ & Lequesne index & $\begin{array}{l}\text { Similar reduction in primary } \\
\text { outcome for both groups. NS } \\
\text { group differences. } \\
\text { Drop out } n=1(0 \mathrm{PHL})\end{array}$ \\
\hline & $\begin{array}{l}\text { (iv) Comparative } \\
\text { DB, RCT }\end{array}$ & $\begin{array}{l}\text { (iv) } 60 \\
\text { (ref 45) }\end{array}$ & $\begin{array}{l}\text { WOB } 3 \times 4 \\
\text { tabs/day }(540 \\
\text { mg/day bromelain }) \\
\text { versus DF } \\
(100-150 \mathrm{mg} / \text { day })\end{array}$ & $\begin{array}{l}\text { OA of the } \\
\text { knee joint }\end{array}$ & 3 weeks & NK & $\begin{array}{l}\text { No SAE reported } \\
\text { but } 30 \mathrm{ADR} \\
\text { (15 WOB; } 15 \mathrm{DF})\end{array}$ & Lequesne index & $\begin{array}{l}\text { Similar reduction in primary } \\
\text { outcome for both groups. NS } \\
\text { group differences. Drop } \\
\text { out } n=2(1 \mathrm{WOB})\end{array}$ \\
\hline $\begin{array}{l}\text { Singer and } \\
\text { Oberleitner (26) }\end{array}$ & $\begin{array}{l}\text { Comparative } \\
\text { DB, RCT }\end{array}$ & 80 & $\begin{array}{l}\text { WOB } 4 \times 7 \\
\text { tabs/day }(945 \mathrm{mg} / \\
\text { day bromelain) } \\
\text { versus DF } \\
(100 \mathrm{mg})\end{array}$ & $\begin{array}{l}\text { OA of the } \\
\text { knee joint }\end{array}$ & 4 weeks & 4 weeks & $\begin{array}{l}\text { No SAE reported. } \\
22 \text { ADR (13 WOB) } \\
\text { Mainly GI but allergic } \\
\text { skin reaction in } n=1\end{array}$ & $\begin{array}{l}\text { Mobility and pain } \\
\text { (five point scale) } \\
\text { in morning }\end{array}$ & $\begin{array}{l}\text { Equivalence not tested but } \\
\text { similar reductions in primary } \\
\text { outcome for both groups. NS } \\
\text { group differences. Drop outs } \\
n=12(8 \mathrm{WOB} ; 4 \mathrm{DF})\end{array}$ \\
\hline $\begin{array}{l}\text { Klein \& } \\
\text { Kullich (27) }\end{array}$ & $\begin{array}{l}\text { Comparative } \\
\text { DB, RCT }\end{array}$ & 73 & $\begin{array}{l}\text { PHL } 3 \times 2 \text { tabs/ } \\
\text { day }(540 \mathrm{mg} / \text { day } \\
\text { bromelain) } \\
\text { versus DF } \\
(100-150 \mathrm{mg} / \text { day })\end{array}$ & Knee OA & 3 weeks & 4 weeks & $\begin{array}{l}1 \text { in } 36(2.8 \%) \\
\text { (headache probably } \\
\text { not related) }\end{array}$ & $\begin{array}{l}\text { Lequesne index } \\
\text { (pain and function) }\end{array}$ & $\begin{array}{l}\text { Reduction in pain indices by } \\
80 \% \text { sustained at } 4 \text { weeks post } \\
\text { treatment. Equivalence was } \\
\text { identified at week } 3 \text { (Mann } \\
\text { Whitney }=0.47 \text { ) and week } 7 \\
\text { (Mann Whitney }=0.55 \text { ) }\end{array}$ \\
\hline Singer et al. (28) & $\begin{array}{l}\text { Comparative } \\
\text { DB, RCT }\end{array}$ & $\begin{array}{l}68 \\
(\mathrm{ref} 37)\end{array}$ & $\begin{array}{l}\text { PHL } 3 \times 2 \text { tabs/ } \\
\text { day }(540 \mathrm{mg} / \mathrm{day} \\
\text { bromelain) versus } \\
\text { DF }(100-150 \mathrm{mg} / \\
\text { day })\end{array}$ & $\begin{array}{l}\text { OA of the knee } \\
\text { joint }\end{array}$ & 3 weeks & 4 weeks & $\begin{array}{l}\text { No SAE reported. } \\
14 \mathrm{ADR} \text { (7 PHL; } \\
7 \mathrm{DF})\end{array}$ & $\begin{array}{l}\text { Lequesne index and } \\
\text { sum of pain scores }\end{array}$ & $\begin{array}{l}\text { PHL group showed significant } \\
>\text { reduction compared to DF } \\
\text { for both Lequesne }(P=0.017) \\
\text { and sum of pain scores } \\
(P=0.047) \text {. Drop out } \\
n=5 \text { (3 PHL) }\end{array}$ \\
\hline
\end{tabular}


Table 1. Continued

\begin{tabular}{|c|c|c|c|c|c|c|c|c|c|}
\hline Authors & Study design & $n^{+}$ & Dosage & Condition & $\begin{array}{l}\text { Treatment } \\
\text { period }\end{array}$ & Follow up & Adverse events & Primary outcome & Conclusion \\
\hline Tilwe et al. 2001 (29) & $\begin{array}{l}\text { Comparative } \\
\text { SB, RCT }\end{array}$ & 50 & $\begin{array}{l}\text { PHL } 4 \times 7 \mathrm{tabs} / \\
\text { day }(1890 \mathrm{mg} / \\
\text { day bromelain) } \\
\text { versus DF } \\
(100-150 \mathrm{mg} / \text { day })\end{array}$ & $\begin{array}{l}\text { Arthritis of } \\
\text { the knee }\end{array}$ & 3 weeks & 4 weeks & $\begin{array}{l}\text { 'well tolerated'; } \\
\text { specific AE not } \\
\text { reported. }\end{array}$ & $\begin{array}{l}\text { Likert scale to } \\
\text { assess pain }\end{array}$ & $\begin{array}{l}\text { Equivalence not tested. } \\
\text { Reduction in pain (NS), } \\
\text { tenderness }(P<0.05) \text { and } \\
\text { swelling (NS) in both groups. } \\
\text { Joint tenderness was } \\
\text { significantly greater } \\
(P<0.05) \text { in PHL group } \\
\text { than DF group }\end{array}$ \\
\hline Walker et al. (30) & $\begin{array}{l}\text { Open. } \\
\text { Dose ranging }\end{array}$ & 77 & $\begin{array}{l}\text { Bromelin }^{\mathrm{TM}} \\
200 \text { or } \\
400 \mathrm{mg} / \text { day }\end{array}$ & $\begin{array}{l}\text { Mild, acute } \\
\text { knee pain }\end{array}$ & 4 weeks & 4 weeks & $\begin{array}{l}\text { No SAE. Minor } \\
\text { AE }(n=19) \\
\text { mainly GI }\end{array}$ & $\begin{array}{l}\text { WOMAC i.e. total } \\
\text { score, pain, stiffness } \\
\text { and function }\end{array}$ & $\begin{array}{l}\text { Significant WOMAC total } \\
\text { score at both doses } \\
(P=0.0001 \text { for } 200 \mathrm{mg} ; \\
P=0.000001 \text { for } 400 \mathrm{mg}) \\
\text { Significant difference between } \\
\text { groups for total score } \\
{[(P=0.036), \text { stiffness }} \\
(0.026), \text { physical function } \\
(0.021), \text { well-being. }]\end{array}$ \\
\hline
\end{tabular}

${ }^{+}$Citations quoted in this column refer to references contained within publications listed in the first column.

PHL, Phlogenzym; WOB, Wobenzym; DF, diclofenac; DB, double blind; SB, single blind; RCT, randomised controlled trial; AE, adverse event; SAE, serious adverse event; ADR, adverse drug reaction; GI, gastrointestinal; WOMAC, Western Ontario McMaster University Arthritis Index; NK, not known; NS, not significant.

gastrointestinal, WOMAC, Western Ontario McMaster University Arthrits lnex, NK, not Known, NS, hot signifint. tablet contains: bromelain $(45 \mathrm{mg})$, papain $(60 \mathrm{mg})$ trypsin $(24 \mathrm{mg})$, chymotrypsin $(1 \mathrm{mg})$, pancreatin $(100 \mathrm{mg})$, lipase $(100 \mathrm{mg})$, amylase (100 mg), rutin $(50 \mathrm{mg})$. 
Four published studies reported trials to assess the effectiveness of bromelain for knee osteoarthritis (26-29). These studies used similar treatment periods ( 3 or 4 weeks) and similar daily doses of a standard treatment, DF (150-100 mg/day); however, different doses of bromelain were tested (range from 540 to $1890 \mathrm{mg} /$ day). The first study reported by Singer and Oberleitner (26) assessed bromelain at a dose of $945 \mathrm{mg} / \mathrm{day}$ (which is higher than that used in most studies) versus DF after 4 weeks of treatment, and although assessment of equivalence was not reported, both groups showed similar reductions in the primary outcome. However, there were more adverse drug reactions (mainly gastrointestinal: 13 in the WOB group versus nine in the DF group) and drop-outs (20\% WOB versus $10 \% \mathrm{DF}$ ) as compared to the standard treatment group, which raises concerns about the safety and tolerability of bromelain at this higher dose. These safety and tolerability issues were not replicated in the study by Tilwe et al. (29) who administered a daily bromelain dose of $1890 \mathrm{mg}$ /day (in the form of the complex PHL) against the DF comparative group. Equivalence was not tested in this study, but both groups showed reduced symptoms of pain and swelling (comparable across groups), and also joint tenderness (the improvement was significantly better in the PHL group). Tolerability was deemed good (there were no drop-outs), and no significant safety issues were raised in this study despite the high dose employed. The final comparative study was reported by Singer et al. (28) who compared bromelain (in the complex PHL) at a dose of $540 \mathrm{mg} /$ day against DF in 68 subjects. This study demonstrated that bromelain showed significantly better improvement in both the primary outcome (Lequesne index, $P=0.017)$ and summary pain scores $(P=0.047)$ as compared to DF. Tolerability and safety were acceptable and levels were similar in both treatment groups. In summary, the four comparative trials indicate that bromelain appears to be as effective as the standard treatment in osteoarthritis of the knee, but higher doses may be associated with safety concerns.

Finally, Walker et al. (30) recently described an open study of one month treatment intervention of bromelain using two dose regimes (200 and $400 \mathrm{mg}$ ) in otherwise healthy adults $(n=77)$ with acute knee pain with no medical diagnosis. The data identified a significant clinical improvement compared to baseline in both the primary outcome [symptoms assessed by the Western Ontario McMaster University Arthritis Index, WOMAC (32)] and in the secondary outcomes (overall psychological wellbeing), at both doses. Furthermore, mean improvements in total symptom score, stiffness and physical function and psychological well-being were significantly greater in the high-dose compared with the low-dose group. However, definitive conclusions cannot be drawn from this study since there are a number of methodological shortcomings. These include the issue of power, which was not addressed: there was no control group (and therefore bias cannot be eliminated) and these patients did not have a formal diagnosis of their knee pain.

In conclusion, bromelain appears to have potential for the treatment of knee osteoarthritis. However it is important to note that there are a number of methodological issues that are common to the studies reported, including the possibility of inadequate power, inadequate treatment periods, inadequate or non-existent follow-up to monitor possible adverse drug reactions. Furthermore, the optimum dosage for this condition remains unclear. A phase II clinical trial would be beneficial to identify the optimal dosage and to systematically monitor safety issues before a definitive efficacy study could be completed.

\section{Bromelain for Osteoarthritis of the Shoulder}

Two studies have assessed the use of bromelain in osteoarthritis of the shoulder (31, Klein, 1994, unpublished data) (Table 2). Both studies have assessed the complex PHL, which has been used at the same daily dose (equivalent of $540 \mathrm{mg}$ bromelain per day) and for the same treatment period of 3 weeks with no follow-up. The first study (by Klein, 1994) is an unpublished report of a double blind placebo controlled trial assessing PHL in 60 patients. No significant difference in treatment groups was observed after treatment. The level of adverse drug reactions and rate of drop out was low. However, there are a number of methodological caveats. It is unclear if the study was adequately powered to detect treatment group differences and, as with the knee osteoarthritis studies, the treatment period and lack of follow-up period are inadequate and the optimum dosage is not clear. The second study by Klein et al. (31) was designed to compare PHL against the standard DF treatment $(100 \mathrm{mg} / \mathrm{day})$ in $n=40$ patients with this condition. No group differences in the primary outcome measures (summary pain score) were observed and safety and tolerability were adequate at this dose. However, this study also suffers from possibly being inadequately powered, a brief treatment period and limited follow up.

In conclusion the data from these two studies do not provide support for the effectiveness and safety of bromelain in osteoarthritis of the shoulder; further studies are needed that are adequately powered to identify the optimal dose and optimal treatment period for this condition.

\section{Summary of Clinical Trials Assessing Bromelain for Osteoarthritis}

The use of bromelain for the treatment of osteoarthritis looks promising. However, a number of methodological caveats indicate that further studies are warranted, in particular phase II clinical trials to identify the optimum dosage, followed by a definitive randomised placebo-controlled trial to confirm its efficacy in the treatment of osteoarthritis.

\section{Bromelain and Adverse Events}

Bromelain has been used as treatment for a number of disease conditions, in addition to osteoarthritis of the knee and shoulder joints (Table 1). No serious adverse events have been reported with the consumption of either bromelain or pineapples in these studies. Adverse events that have been reported are 


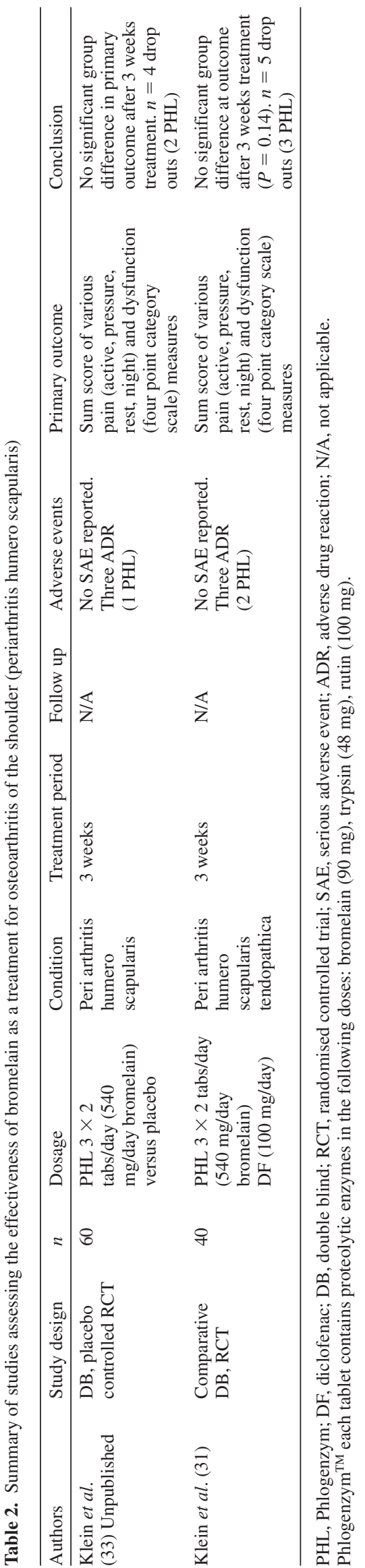

mainly gastrointestinal (i.e. diarrhoea, nausea and flatulence), but have also included headache, tiredness, dry mouth, skin rash and allergic reactions (not specified).

The trials assessing bromelain in osteoarthritis have used doses of bromelain in the range 540-1890 mg/day. Safety and tolerability for bromelain at the lower dose appears good with similar if not better safety profiles as compared to standard treatment. However, the studies that have used a higher daily dose of bromelain [945 mg/day (26); $1890 \mathrm{mg} /$ day (29)] appear to be conflicting. The authors employing the highest dose reported that the medication was well tolerated; the dose of $945 \mathrm{mg} /$ day, however, showed a higher incidence of adverse drug reactions and drop-outs as compared to the profiles from the standard NSAID treatment group. A formal phase II study is needed to identify safety and efficacy/effectiveness of bromelain. In addition, it is conceivable that patients would clinically receive bromelain for longer treatment periods than have been assessed by the current osteoarthritis studies. Further work is therefore needed to evaluate the long-term safety of this supplement. Finally, there are also a number of other potential safety issues that need to be addressed. These include investigating the possibility of renal effects (because of modulation of biosynthesis of prostaglandins), potentiating effects on the action of anticoagulants [e.g. warfarin (33)] and enhanced absorption of antibiotics (11).

\section{Dosage in human studies}

The review by Maurer (11) identified that bromelain has been used in the daily dosage range of 200-2000 mg, with therapeutic action shown at $160 \mathrm{mg} /$ day. The trials assessing bromelain in osteoarthritis have used bromelain at a higher therapeutic dose, in the range of 540-1890 mg/day. Safety and tolerability at the lower dose appears to be good; the data indicates that bromelain at this dose appears to be as effective as standard treatment with at least similar safety and tolerability profiles. The two studies employing a higher daily dose [945 mg/day (26) and $1890 \mathrm{mg} /$ day (29), both comparative trials] showed that the dose of $945 \mathrm{mg}$ /day showed similar outcomes to DF, whereas 1890 $\mathrm{mg}$ /day appeared to be superior to DF in one of the primary outcome measures (joint swelling). As yet there have been no formal phase II studies to assess the optimal dose. However, the recent study by Walker et al. (30) in acute knee pain showed a significant dose-dependent effect between the two doses of 200 and $400 \mathrm{mg}$ per day, over a period of one-month therapy. Further study is needed to identify the optimal dose for the treatment of chronic joint inflammation over longer periods of time (e.g. 3-4 months) within a blinded and randomised trial.

\section{Summary}

The currently available data do indicates the potential of bromelain in treating osteoarthritis. However, further studies are needed before a definitive conclusion can be drawn. Specifically, there is a need for trials to establish efficacy, and dose ranging studies to identify the optimum dosage (with 
adequate prospective adverse event monitoring). Finally, future work should focus on the dose-response parameters and efficacy of long-term bromelain use in chronic conditions such as osteoarthritis.

\section{Conflict of Interest}

Dick Middleton is consultant to Lichtwer Pharma UK Ltd who manufacture bromelain. Steven Hicks was funded by Lichtwer for a post-graduate fellowship from 1998 to 2002.

\section{Acknowledgements}

S.B. is funded by a grant from the Hospital Savings Association. G.L. is funded by a grant from the Maurice Laing Foundation. A.W. and S.M.H. are funded by The University of Reading.

\section{References}

1. Lawrence RC, Helmich CG, Arnett F, et al. Estimates of prevalence of arthritis and selected musculoskeletal disorders in the United States. Arthritis Rheum 1998;41;778-99.

2. Felson DT, Lawrence RC, Dieppe PR, et al. Osteoarthritis: New Insights. Part 1. The disease and its risk factors. Ann Intern Med 2000; 133;635-46.

3. Guccione AA, Felson DT, Anderson JJ, et al. The effects of specific medical conditions on the functional limitations of elders in the Framington study. Am J Public Health 1994;84;351-8.

4. Doherty M. Risk factors for the progression of knee osteoarthritis. Lancet 2001;358;775-6.

5. Anderson JJ, Felson DT. Factors associated with osteoarthritis of the knee in the first national Health and Nutrition Examination Survey (HANES I). Evidence for an association with overweight, race, and physical demands of work. Am J Epidem 1988;128:179-89.

6. Minor MA, Hewitt JE, Webel RR, Anderson SK, Kay DR. Efficacy physical conditioning exercise in patients with rheumatoid arthritis and osteoarthritis. Arthritis Rheum 1989;32:1396-1405.

7. Singh G. Recent considerations in nonsteroidal anti-inflammatory drug gastropathy. Am J Med 1998;105(16):315-85.

8. Griffin MR. Epidemiology of nonsteroidal anti-inflammatory drug-associated gastrointestinal injury. Am J Med 1998;104 (3A):23S-29S.

9. Wright JM. The double-edged sword of COX-2 selective NSAIDs. Can Med Assoc J 2002;167:1131-7.

10. Cooreman WM, Scharpe S, Demeester J, Lauwers A. Bromelain, biochemical and pharmacological properties. Pharm Acta Helv 1976;51:73-97.

11. Maurer HR. Bromelain: biochemistry, pharmacology and medical use. Cell Mol Life Sci 2001;58:1234-45.

12. Taussig SJ, Batkin S. Bromelain, the enzyme complex of Pineapple (Ananas comusus) and its clinical application. An update. $J$ Ethnopharmacol 1988;22:191-230.

13. Pirotta F, de Giuli-Morghen C. Bromelain: anti-inflammatory and serum fibronolytic activity after oral administration in the rat. Drugs Exp Clin Res 1978;4:1-20.
14. Livio M, Bertoni MP, De Gaetano G, Donati MB. Effects of bromelain on fibrinogen level, pothrombin complex and platelet aggregation in the rat-a preliminary report. Drugs Exp Clin Res 1978;4:49-53.

15. Kumakura S, Yamashita M, Tsurufuji S. Effect of Bromelain or kaolininduced inflammation in rats. Eur J Pharmacol 1988;150:295-301.

16. Hale LP, Hayes BF. Bromelain treatment of human T cells removes CD44, CD45RA, E2/MIC2, CD6, CD7, CD8 and Leu 8/LAM1 surface molecules and markedly enhances CD-2Mediated T cell activation. $J$ Immunol 1992;149:3809-16.

17. Kleef R, Delohery TM, Bovbjerg DH. Selective modulation of cell adhesion molecules on lymphocytes by Bromelain protease 5. Pathobiology 1996;64:339-46.

18. Mynott T, Ladhams A, Scarmato P, Engwerda C. Bromelain from pineapple stems, proteolytically blocks activation of extracellular regulated kinase-2 in T cells. J Immunol 1999;163:2568-75.

19. Hale LP, Greer PK, Sempowski GD. Bromelain treatment alters leukocyte expression of cell surface molecules involved in cellular adhesion and activation. Clin Immunol 2002;104;183-90.

20. Hale LP. Proteolytic activity and immunogenicity of oral bromelain within the gastrointestinal tract of mice. Int Immunopharm 2004;4:255-64.

21. Mojcik C, Shevach E. Adhesion molecules: a rheumatologic perspective. Arthritis Rheum 1997;40:991-1004.

22. Bodi T. The effects of oral bromelains on tissue permeability to antibiotics and pain response to bradykinin: double blind studies on human subjects. Clin Med 1966;73:61-5.

23. Uhlig G, Seifert J. Die Wirkung proteolytischer Enzyme auf das posttraumatische Syndrom. Fortschritte der Medizin 1981;15:554-6.

24. Cohen A, Goldman J. Bromelain therapy in rheumatoid arthritis. Penn Med J 1964;67:27-30.

25. Leipner J, Iten F, Saller R. Therapy with proteolytic enzymes in rheumatic disorders. Biodrugs 2001;15:779-89.

26. Singer F, Oberleitner H. Drug therapy of activated arthrosis. On the effectiveness of an enzyme mixture versus diclofenac. Wien Med Wochenschr 1996;146:55-8.

27. Klein G, Kullich W. Short-term treatment of painful osteoarthritis of the knee with oral enzymes: a randomised, double-blind study versus Diclofenac. Clin Drug Invest 2000;19:15-23.

28. Singer F, Singer C, Oberleitner H. Phlyoenzym versus diclofenac in the treatment of activated osteoarthritis of the knee. Int J Immunother 2001; 17:135-41.

29. Tilwe GH, Beria S, Turakhia NH, Daftary GV, Schiess W. Efficacy and tolerability of oral enzyme therapy as compared to diclofenac in active osteoarthritis of the knee joint: an open randomised controlled clinical trial. Journal of the Association of Physicians of India. JAPI 2001;49:621.

30. Walker AF, Bundy R, Hicks SM, Middleton RW. Bromelain reduces mild acute knee pain and improves well being in a dose dependant fashion in an open study of otherwise healthy adults. Phytomedicine 2002;9:681-6.

31. Klein G, Kullich W, Brugger A. Phlogenzym in der Behandlung der Periarthropathia humeroscapularis tendopathica simplex. Arzt Praxis 1997;51:879-85.

32. Bellamy N, Buchanan W, Goldsmith C, Campbell J, Stitt L. Validation study of WOMAC: a health status instrument for measuring clinically important patient relevant outcomes to anti-rheumatic drug therapy in patients with osteoarthritis of the hip or knee. Rheumatology 1988;15:1833-40.

33. Stenton SB, BungardTJ, Ackman ML. Interactions between warfarin and herbal products, minerals, and vitamins: A pharmacist's guide. Can J Hosp Pharm 2001;54:184-90.

Received February 9, 2004; accepted July 29, 2004 


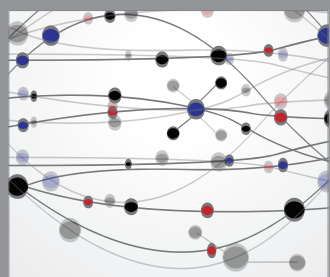

The Scientific World Journal
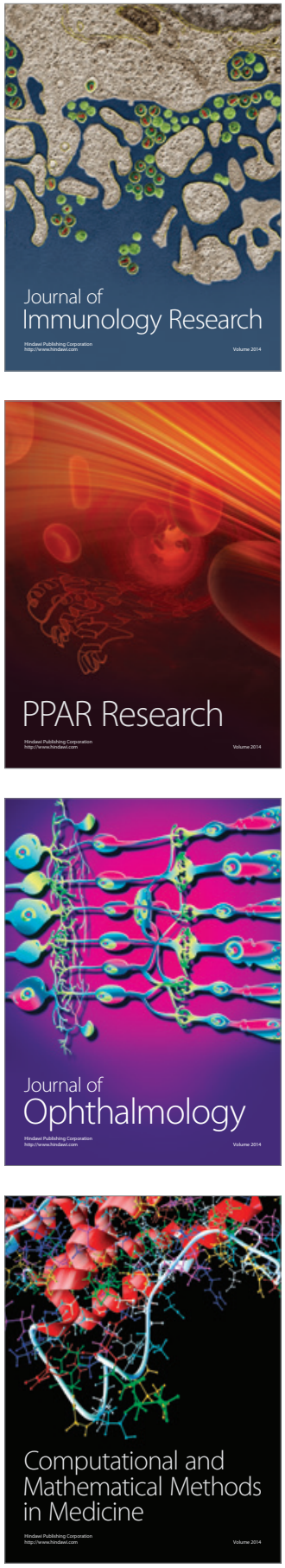

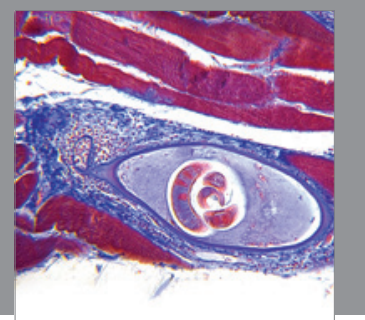

Gastroenterology

Research and Practice
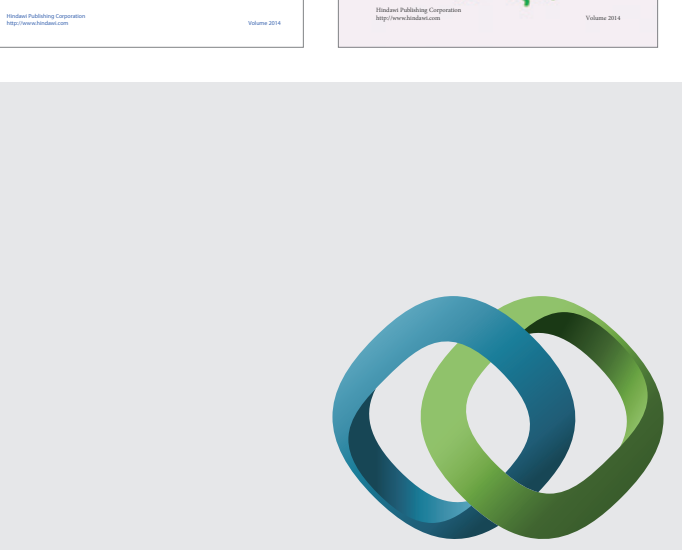

\section{Hindawi}

Submit your manuscripts at

http://www.hindawi.com
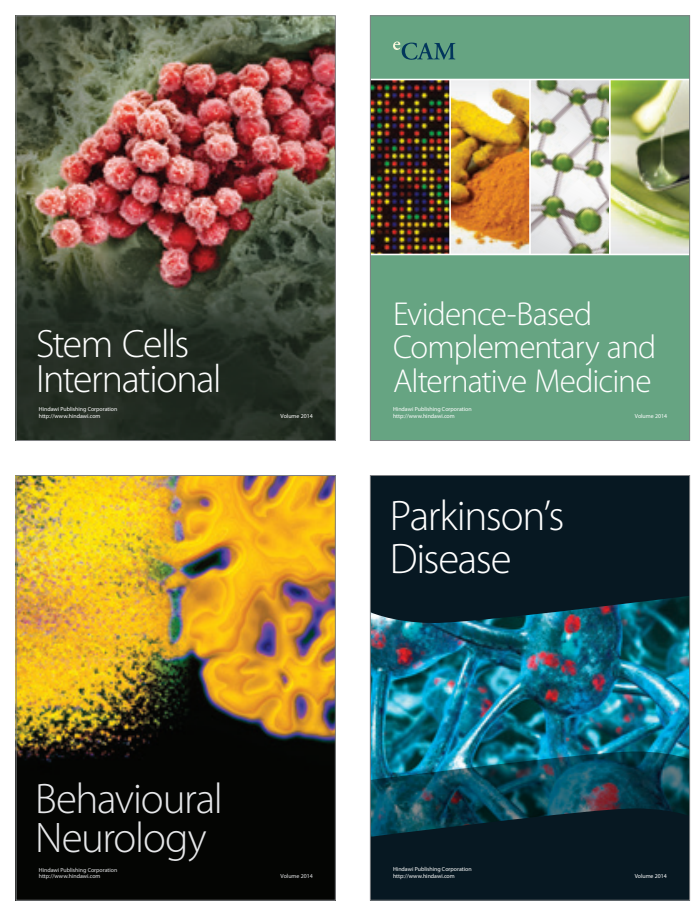

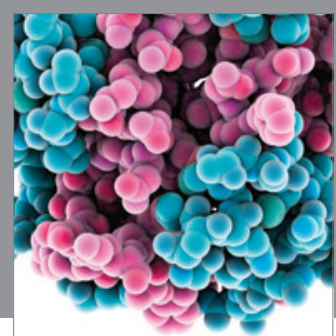

Journal of
Diabetes Research

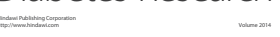

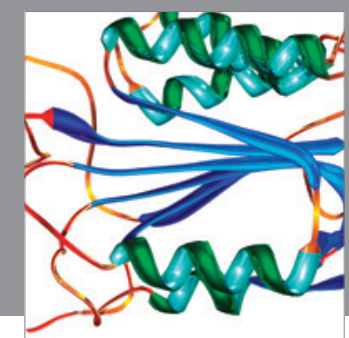

Disease Markers
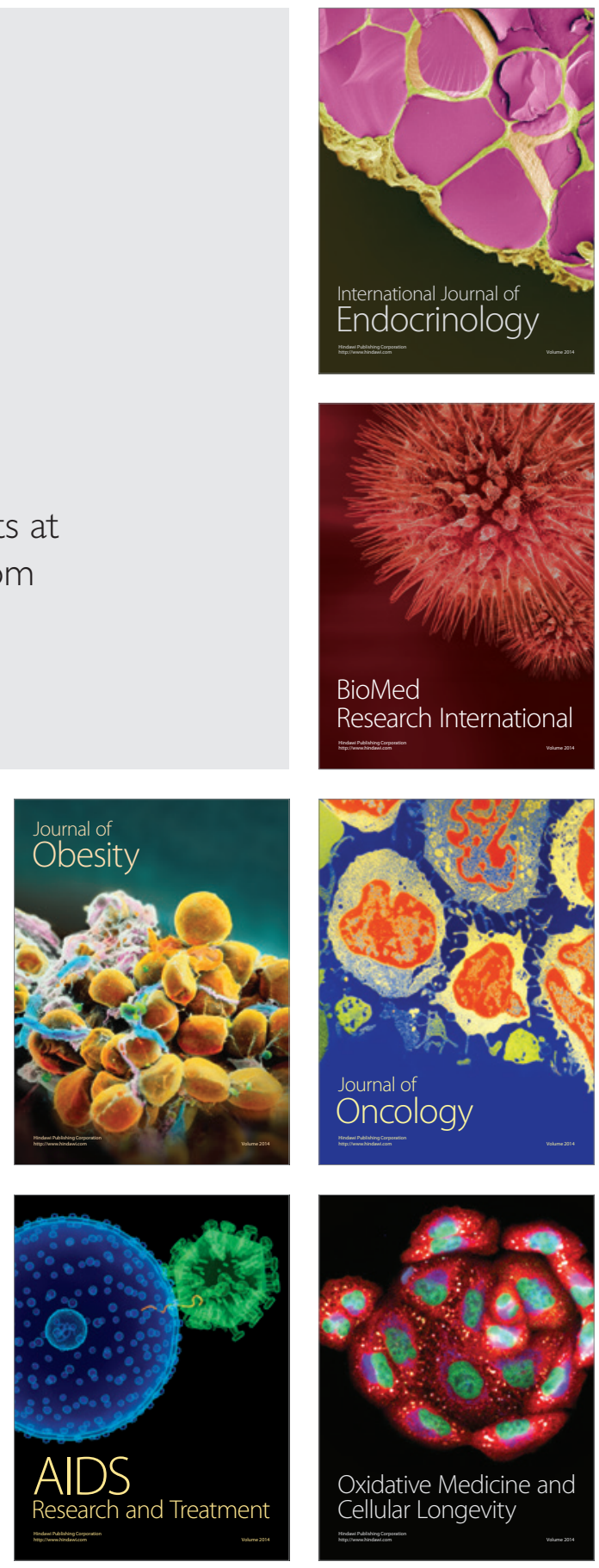